\title{
Rosuvastatin-induced rhabdomyolysis - the possible role of ticagrelor and the patient's pharmacogenetic profile: a case report
}

\section{Iva Ladić', \\ Majda Vrkić Kirhmajer" Krešimir Putarek ${ }^{2}$, Ljiljana Banfić Nada Božina ${ }^{2}$}

'Bjelovar General Hospital, Bjelovar, Croatia

2University of Zagreb School of Medicine, University Hospital Centre Zagreb, Zagreb, Croatia
RECEIVED:

January 31, 2018

ACCEPTED:

February 10, 2018

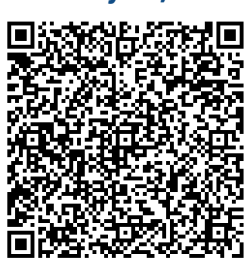

KEYWORDS: rhabdomyolysis, rosuvastatin, ticagrelor.

CITATION: Cardiol Croat. 2018;13(1-2):36. | https://doi.org/10.15836/ccar2018.36

*ADDRESS FOR CORRESPONDENCE: Majda Vrkić Kirhmajer, Klinički bolnički centar Zagreb, Kišpatićeva 12, HR10000 Zagreb, Croatia. / Phone: +385-91-5273-592 / E-mail: majda_vrkic@yahoo.com

ORCID: Iva Ladić, https://orcid.org/0000-0003-0124-5256 • Majda Vrkić Kirhmajer, https://orcid.org/0000-0002-1340-1917 Krešimir Putarek, https://orcid.org/0000-0003-0361-5740 • Ljiljana Banfić, https://orcid.org/0000-0002-4538-8980 Nada Božina, https://orcid.org/0000-0001-6016-1699

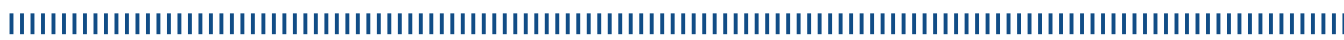

Background: Dual antiplatelet therapy and statins are the cornerstone of acute coronary syndrome (ACS) treatment. Interaction between these drugs can be affected by differences in inter-individual pharmacokinetics/pharmacogenetics. Rhabdomyolysis is adverse reaction of statins. Previous reports suggested that concomitant use of ticagrelor may add an additional risk in developing statin induced rhabdomyolysis. ${ }^{1,2}$ We present a case of rosuvastatin and ticagrelor induced rhabdomyolysis.

Case report: 87-year-old female patient was admitted in the Department of Cardiovascular Diseases because of symptoms and signs of rhabdomyolysis. Her medical history revealed hypertension, chronic renal failure and acute coronary syndrome with percutaneous coronary intervention performed a month before. Her therapy at admission included aspirin $100 \mathrm{mg}$, ticagrelor 2 x $90 \mathrm{mg}$, furosemide 40 mg, potassium $1 \mathrm{gr}$, rosuvastatin $20 \mathrm{mg}$, pantoprazole $40 \mathrm{mg}$, amiodarone $200 \mathrm{mg}$ and bisoprolol $2.5 \mathrm{mg}$. Physical examination showed no major abnormalities except muscle pain and weakness. Laboratory parameters were: serum creatinine kinase (CK) $19182 \mathrm{U} / \mathrm{L}$, creatinine $306 \mu \mathrm{mol} / \mathrm{L}$, mild hepatic lesion and red cells in urine analysis, suggesting that patient had developed rhabdomyolysis and progression of chronic renal failure. Despite rosuvastatin and amiodarone discontinuation CK rose further to 23974 U/L. On $5^{\text {th }}$ day of hospitalization a mild decrease of CK values was noticed while clinical symptoms remained unchanged. On $7^{\text {th }}$ day ticagrelor was discontinued and shortly after a rapid normalization of $\mathrm{CK}$ was recorded with mild renal function improvement. The patient declared regression of symptoms with complete recovery in few days. Real-time PCR based pharmacogenetic analyses indicated that the patient was carrier of low activity alleles of metabolic enzymes (CYP3A4*22, CYP2C9*3, UGT2B7$161 \mathrm{C} / \mathrm{T}$ ) and ABCB1 drug transporter which could prolong ticagrelor and rosuvastatin dispositions.

Conclusion: Our patient had several risk factors for rhabdomyolysis: old age, renal and hepatic impairment, drug interactions and genetic predisposition. Pharmacogenetic analysis can provide additional information about mechanism of this interaction and help in tailoring an individual statin and antiplatelet therapy. Neth J Med. 2015;73(3):136-8. PubMed: https://www.ncbi.nlm.nih.gov/pubmed/25852115

2. Teng R, Mitchell PD, Butler KA. Pharmacokinetic interaction studies of co-administration of ticagrelor and atorvastatin or simvastatin in healthy volunteers. Eur J Clin Pharmacol. 2013 Mar;69(3):477-87. https://doi.org/10.1007/s00228-012-1369-4 